22. Ибрагимов Н.Г. Медицинская общественность и ее роль в охране здоровья населения. Уфа, 1984. C. 53.

23. Чикин С.Я. Развитие здравоохранения в РСФСР. M., 1977. C. 21.
24. Центр документации новейшей истории Оренбургской области. Ф. 1. Оп. 1. Д. 1180. Л. 95.

25. ЦГИАРБ. Ф. Р-444. ОП. 1. Д. 49. Л. 64.

26. Оренбургская коммуна. 1936. 5 окт.

27. ЦГИАРБ. Ф. Р-444. Оп. 1. Д. 148а. Л. 96.

\title{
SOUTHERN URALS HEALTH AUTHORITIES' ACTIVITIES IN COMBATING MALARIA IN THE FIRST DECADES OF THE SOVIET POWER
}

(C) 2017

\author{
Klementeva Natalia Vladimirovna, candidate of historical sciences, \\ associate professor of Russian History Department \\ Orenburg State Pedagogical University (Orenburg, Russian Federation)
}

\begin{abstract}
The paper considers one of the most important areas of sanitary and epidemiological activity of central and regional health authorities - the fight against the epidemic of malaria in the first decades of the Soviet power. It is concluded that a high incidence of malaria in Russia was recorded as early as the pre-revolutionary period, and the medical community took certain steps to combat it. However, malaria prevailed in the first decades of the Soviet power. The causes of malaria spread that led to the epidemic are directly related to the complex socio-economic and political situation that prevailed during this period. In this regard, public authorities and health authorities almost immediately gave the fight against malaria a national character. In an expeditious manner, they developed normative legal documents and action plans for combating malaria, especially in especially affected areas, to which the South Urals can be fairly attributed. The implemented measures brought their positive results, but the fight against malaria was complicated by a lack of funding and, accordingly, many activities were carried out late and not in full. Therefore, in 1930 the fading epidemic of malaria broke out with renewed vigor, which was finally eliminated on the territory of the USSR only by the 1960 s.

Keywords: malaria; epidemic; People's Commissariat of Health; Provincial Health Department; Orenburg province; Bashkir ASSS; Chelyabinsk province; Southern Urals; antimalarial measures; malarial station; oil refining; chinization; civil war; revolution; intervention; drought; famine; crop failure.
\end{abstract}

УДК 93/94

\section{ИЗЬЯТИЕ ЦЕРКОВНЫХ ЦЕННОСТЕЙ В ЕНИСЕЙСКОЙ ГУБЕРНИИ (К ВОПРОСУ О ПЕРИОДИЗАЦИИ И ИТОГАХ)}

(C) 2017

\author{
Вдовин Александр Сергеевич, кандидат исторических наук, \\ профессор кафедры музеологии и культурного наследия \\ Бобрик Илья Евгеньевич, студент исторического факультета \\ Красноярский государственньй педагогический университет им. В.П. Астафьева \\ (2. Красноярск, Российская Федерачия)
}

\begin{abstract}
Аннотация. В центре внимания данной статьи находится процесс изъятия церковных ценностей, происходящий в Енисейской губернии в марте 1922 г. - марте 1923 г., поводом для реализации которого стал, как известно, голод в губерниях Поволжья. Авторы на основе центральных и региональных архивов пересматривают итоги кампании, описанные ранее в региональной историографии, дают периодизацию данного процесса в региональном контексте. По мнению авторов, изъятие церковных ценностей в Енисейской губернии проходило в три неравномерно протекающих этапа, один из которых затянулся более чем на полгода. Периодизация основана на делопроизводственной связи г. Красноярска и г. Москвы по вопросу изъятия церковных ценностей. Енисейская губерния, как одна из самых отстающих в проведении этой кампании, значительно задерживала ее завершение. Сверка различных архивных данных, свидетельствующих об итогах кампании, показала разнообразие чисел и неопределенность в подведении итогов. Авторы проследили путь ценностей, изъятых в губернии, от сдачи уездным комиссиям до Енисейского губфинотдела, от Енисейского губфинотдела до Уральской золотосплавочной лаборатории (г. Екатеринбург) и далее до Москвы.

Ключевые слова: Церковь и Советское государство; церковные ценности; изъятие; Русская православная церковь; Енисейская губерния; Помгол; Приенисейская Сибирь; религиозные организации; голод в Поволжье; Енисейская епархия; церковное серебро; антирелигиозная политика; экономическая политика.
\end{abstract}

С начала 1990-х гг., в связи с наступившими изменениями в общественно-политической жизни страны, методологической трансформацией исторической науки, количество исследований, посвященных государственно-конфессиональным взаимоотношениям в Советской России, резко увеличилось. В это же время и вплоть до настоящего времени проводится изучение кампании по изъятию церковных ценно- стей, подлинные цели, задачи и итоги реализации которой на протяжении всей советской историографии оставались недосказанными как по причине узости источниковой базы, так и по идеологическим соображениям. Исследования, проведенные М.И. Одинцовым [1], О.Ю. Васильевой [2], Н.А. Кривовой [3], И.В. Говоровой [4], продемонстрировали неоднозначность воплощения кампании, а помощь голодаю- 
щим Поволжья, как оказалось, являлась лишь поводом и официальным рычагом для продолжения раскола в рядах религиозных организаций. В указанный период времени наблюдается регионализация исследований, посвященных изъятию церковных ценностей. В Сибири изучение кампании проводится на материалах г. Омска [5], Алтая [6], Тюменской [7], Иркутской [8] областей, Байкальской Сибири [9] и др. Локальное исследование хода кампании позволяет более детально воспроизвести механизм реализации изъятия церковных ценностей, учитывая региональный контекст и особенности проведения кампании в провинции.

Изъятию церковных ценностей в Приенисейской Сибири посвящен ряд работ, в которых всестороннее изучение кампании не является целью исследования. Наиболее основательно этот вопрос рассмотрен А.П. Доброновской в публикациях [10], а затем - в диссертационном исследовании [11]. Последнее посвящено религиозной жизни населения Приенисейской Сибири в 1905-1929 гг., поэтому само изъятие церковных ценностей в большей степени рассматривается в контексте восприятия кампании населением. Автором освещены общие сведения о составе комиссии по изъятию, о начале кампании, её ходе по некоторым сводным отчетам, приводятся списки газетных статей об изъятии. При этом, в силу того что изъятие церковных ценностей не являлось предметом исследования, как и сам экономический аспект религиозной политики Советского государства, за рамки исследования вышли многие стороны кампании [12, с. 33].

Публикацию М.В. Холиной можно считать одной из первых в регионе, где изъятие церковных ценностей рассматривается в общем контексте экспроприации религиозного имущества. Автор упоминает три «кампании по изъятию церковных ценностей», проходивших в 1920 [13, с. 31], 1922 [13, с. 33] и 1924 $[13$, с. 36$]$ гг., хотя собственно «изъятие» как кампания относится только к 1922 г.

В историко-публицистической монографии по епархиальной истории Приенисейской Сибири, написанной представителем Красноярской епархии Г.В. Малашиным, «безжалостное изъятие» рассматривается с духовно-нравственных позиций, уделяется большое внимание «кощунственному надругательству над святынями», «цинизму» большевиков, «грабивших» храмы и др. [14, с. 308].

В ряде статей, посвященных енисейскому крестьянству, также упоминается кампания по изъятию ценностей в губернии. Так, в работах историка А.П. Шекшеева приводятся факты сопротивления изъятию церковных ценностей в енисейской деревне. Автор полагает, что изъятие вызывало недовольство и протесты со стороны сельских прихожан, поэтому кампания в деревнях осуществлялась медленнее, чем в городах [15].

Таким образом, несмотря на то, что проблема изъятия церковных ценностей в Енисейской губернии уже получила развитие в региональной историографии, полная картина по данному вопросу отсутствует.

Целью исследования является разработка периодизации и определение итогов изъятия церковных ценностей в Енисейской губернии, с учетом архив- ных данных региональных и центральных архивов. Предложенная периодизация не является окончательной, возможны иные интерпретации кампании в регионе, итоги же требуют точного определения.

Как известно, во второй половине 1921 г. страну, и без того претерпевающую трудности, настигло еще одно бедствие - голод, более всего ударивший по районам Поволжья. Государственные органы самостоятельно не могли справиться с такой масштабной катастрофой, поэтому уже в июле 1921 г. советское правительство обратилось за помощью к иностранным организациям и к общественности. В дело помощи голодающим включились и религиозные организации. 22 августа 1921 г. Патриарх Тихон выпустил воззвание «О помощи голодающим», в котором призывал всех людей помочь «стране, кормившей многих и ныне умирающей от голода» [17, с. 57-58]. Несмотря на попытки церковных организаций протянуть руку помощи голодающему народу, организовать Церковный комитет помощи голодающим, правительство все же умело использовало ситуацию, сделав так, что добровольные пожертвования превратились в насильственное изъятие. Как справедливо отмечал академик РАН Н.Н. Покровский, любая общественная инициатива властями трактовалось как «уловка классового врага» [16, с. 8]. В итоге с февраля 1922 г. развернулись широкомасштабные мероприятия, охватившие практически всю территорию страны, по учету и реквизиции церковного имущества, агитации против религиозных организаций и расколу Русской православной церкви на «тихоновцев» и «обновленцев».

После принятия декрета ВЦИК об изъятии церковных ценностей от 16 (23) февраля 1922 г., предписывающего «изъять из церковных имуществ» все серебряные, золотые и иные драгоценные предметы, «изъятие коих не может существенно затронуть интересы культа» [17, с. 59], 10 марта 1922 г. Политбюро ЦК приняло решение о создании центральной комиссии по изъятию церковных ценностей (КИЦЦ). С этого времени, по мнению И.В. Говоровой, начинается первый этап изъятия церковных ценностей (26 февраля - 19 марта 1922 г.) [4, с. 21].

Периодизация И.В. Говоровой включает в себя три этапа изъятия церковных ценностей:

- I этап изъятия церковных ценностей (26 февраля - 19 марта 1922 г.) - характеризуется подготовительными мероприятиями, отношением Патриарха Тихона к декрету;

- II этап - основной (20 марта - 26 мая 1922 г.);

- III этап - окончание кампании (лето - осень 1922 г.), включающее в себе «доизъятие» и подсчет итогов [4, с. 21-24].

Указанная периодизация носит общий характер для всей страны, поэтому для учета региональной специфики может быть применима частично. «Изъятие в отдаленных районах продолжалось до осени 1922 г., - отмечает И.В. Говорова, - в ноябре 1922 г. Последгол подвел итоги операции» [4, с. 12]. Приенисейская Сибирь в данном случае являлась одним из таких «отдаленных районов», где ящики с церковными ценностями не прекращали поступать еще и в январе 1923 г. [18, л. 37], поэтому для определения хронологических рамок кампании в регионе необходима несколько иная периодизация. 
А.П. Доброновская в своей диссертации условно выделила два этапа изъятия церковных ценностей в Енисейской губернии:

- первый этап (весна - середина лета 1922 г.): «спокойный и гласный характер» кампании, благодаря планомерным действиям властей и умеренной позиции духовенства;

- второй этап (лето - осень 1922 г.): «затяжной» характер кампании, в силу различных условий, задерживающих завершение кампании, судебные процессы по делу изъятия церковных ценностей [11, c. 137-139].

Данная периодизация отражает общие тенденции реализации кампании, также в периодизацию введен критерий скорости осуществления - на первом этапе ударно, «большевистскими темпами», на втором медленно. Критерий отражает региональную специфику, заключающуюся в затяжном характере проведения кампании, но вместе с тем периодизация не учитывает всех нюансов.

По нашему мнению, изъятие церковных ценностей в Енисейской губернии можно разделить на три этапа:

- Подготовительно-агитационный (12 марта 26 апреля 1922 г.). Хронологические рамки этапа, с одной стороны, ограничены созданием Енисейской губернской комиссии по изъятию церковных ценностей (ЕнгубКИЦЦ), с другой - решением Комиссии о начале изъятия.

- Период активного изъятия (28 апреля - 19 июня 1922 г.). Нижняя граница этапа обусловлена началом изъятия церковных ценностей в губернии из самого богатого храма - Красноярского Кафедрального собора, верхняя - завершением изъятия в большей части уездов губернии.

- Прием иенностей в финотдел и высылка в Центр (июнь 1922 г. - 21 марта 1923 г.). Этап характеризуется началом проведения Енисейским губфинотделом приемки ценностей и составления отчетов изъятых ценностей, с другой стороны - последними сведениями о поступлении ценностей в финотдел и высылке их в Москву.

В Енисейской губернии уже 12 марта была организована «межведомственная комиссия по изъятию церковных ценностей». Точного состава комиссии по протоколу заседания установить невозможно, в силу отсутствия сведений о присутствующих. Можно согласиться с некоторыми исследователями, что это подтверждает «секретный» характер комиссии и решающую роль партии $[10$, с. 115$]$. Известно, что председателем ЕнгубКИЦЦ являлся А. Кашников, заместитель председателя губисполкома и заведующий губернским отделом управления. Двумя другими членами комиссии являлись А. Бочков, председатель губернской комиссии Помгола, и В. Гоштофт, заведующий губернским финотделом. Однако в одной сводке ГПУ упоминается еще одна фамилия, которая далее не фигурирует. В сводках за март 1922 г. отмечалось, что среди населения распространяются слухи, будто бы «жиды лезут обирать церкви», поскольку «председатель комиссии по изъятию церковных ценностей еврей (Председатель РКП Коган)» $[19$, л. 120]. Очевидно, председателем Комиссии все же был А.И. Кашников, но роль партийных структур в деле изъятия этим слухом лишь подтверждается.
В тот же день, 12 марта 1922 г., ЕнгубКИЦЦ утвердила план работы, обязав Губюст предоставить списки имущества храмов, составить очередность изъятия, а также организовать уездные подкомиссии в г. Канске, г. Красноярске, г. Минусинске, г. Туруханске в составе членов крайисполкома, Помгола, финотдела. В г. Ачинске и г. Енисейске комиссии должны были быть организованы под председательством особо уполномоченного губисполкома $[10$, c. 115]. Уездные комиссии по изъятию церковных ценностей (уКИЦЦ) были утверждены только 27 мая 1922 г. [20, л. 60]. До конца марта ЕнгубКИЦЦ вела подготовку и проверку списков предназначенного для изъятия церковного имущества, а начало изъятия было намечено на «послепасхальную» неделю. Население, исходя из информационных сводок ГПУ за март 1922 г., было взволновано предстоящей кампанией, велись рассуждения о том, что «голод в Поволжье устроен коммунистами», которые «добрались до Сибири, чтобы привести ее в разорение» [19, л. 117]. В целом, ГПУ отмечало, что население относится к предстоящему изъятию «несочувственно» и с «затаенной злобой», боясь расхищения ценностей или «передела» между «комиссарами Помгола», как это было, к примеру, в г. Смоленске, по мнению железнодорожных рабочих губернии [19, л. 175-176].

Если духовенство, как отмечало ГПУ, в феврале «вело себя пассивно», то в марте «церковные круги» были «сильно взбудоражены слухами о намерении Советской власти» изъять «некоторые ценности» $[19$, л. 120]. У епископа Назария этот вопрос обсуждался дважды: в марте и в апреле. В первом случае, «секретное совещание» отмечалось «воинственным настроем» духовенства, за исключением одного священника, предложившего «не поднимать никакого шума» $[19$, л. 120]. При этом архиерей заявлял собравшемуся духовенству, что у него в Отделе юстиции «рука», и в «случае опасности ему обо всем сообщат» $[19$, л. 120]. Второй раз красноярское городское духовенство собралось в апреле для обсуждения «дальнейшей тактики в деле изъятия», как сообщает ГПУ. Здесь же говорилось о том, что священники «снова опровергали голод в Поволжье», что это «ложь, а вся история с изъятием» не более чем «новый маневр большевиков», дабы «разбить своего последнего врага: церковь и веру» [19, л. 184]. И если первое собрание не вынесло никакого решения, то апрельское собрание постановило «считать изъятие грабежом, ничего не давать и поддерживать соответствующее настроение в кругах верующих» [19, л. 185].

Л.Д. Троцкий, главный идеолог кампании, советовал провести недели агитации и предварительной организации, поскольку дело с изъятием обстояло намного хуже, чем предполагал сам Троцкий. 19 марта 1922 г. предлагалось повсеместно прекратить изъятие церковных ценностей, для того чтобы вести основательную подготовку [21, с. 110-111]. Уже 23 марта председатель ЕнгубКИЦЦ А.И. Кашников указал всем уисполкомам и волисполомам «не приступать к изъятию никаких ценностей до точных указаний, а лишь вести подготовку к изъятию» $[20$, л. 73].

С конца марта и до конца апреля 1922 г. в губернии шла основательная агитационная подготовка 
Вдовин А.С., Бобрик И.Е.

населения к изъятию ценностей. 25 марта на заседании Президиума Енгубкома Комиссия просила у губернского комитета разрешение на проведение беспартийных конференций по г. Красноярску. На следующий день, 26 марта, состоялся митинг об изъятии из храмов золота и серебра, о чем свидетельствует «Красноярский рабочий»: «Около 3-х часов митинг объявляется открытым. Первым говорит Яков Лобанов, бывший священник. Оратор призывал к необходимости изъятия... Тов. Лобанова сменяет священник Василий Сельский. Этот «служитель Алтаря» возражает против изъятия... Своя «публика» конечно, хлопает Сельскому. Но красноармейцы и рабочие...возмущены» [22]. Весь пафос агитационной кампании демонстрирует вооруженная демонстрация с участием детей из голодающих районов Поволжья, прошедшая 24 апреля 1922 г. на Старобазарной площади г. Красноярска, где Енисейскому губисполкому были вручены два требования от красноармейцев и детей с просьбой начать изъятие. Эта акция также нашла отражение в официальной губернской газете: «На броневик взбирается мальчик, лет 12. Он зовет детей просить Губисполком скорее помочь голодающим. От присутствующих детей выносится следующее постановление: «Дети, прибывшие в Красноярск... просят приступить к изъятию драгоценностей...из всех церквей» [23]. Агитации также прошли в воинских частях Канского гарнизона, где солдаты «властно потребовали во имя спасения умирающих» немедленного изъятия церковных ценностей [24], в г. Туруханске было организовано общее собрание граждан, под председательством священника Мироединской Казанской церкви, который взывал к «христианской помощи голодающим» [25, с. 116]. В периодической печати использовались всевозможные средства агитации (фельетоны, обращения верующих, публицистические заметки, интервью с духовенством и пр.) для основательной подготовки населения, но, как отмечает А.П. Доброновская, «местные органы ГПУ признавались, что «изъятие, еще не начавшись, во многих волостях губернии уже сорвано»»), хотя духовенство призывало верующих «не оказывать сопротивления органам местной власти» $[11$, с. 137$]$.

26 апреля 1922 г. на заседании ЕнгубКИЦЦ было принято решение о проведении первого изъятия в губернии, как и предписывалось Центром, с самых богатых храмов. Необходимо было провести первое изъятие в православной церкви, в полном составе, пригласив экспертов по оценке имущества и представителя от музея.

Второй этап изъятия церковных ценностей в Енисейской губернии начинается 28 апреля 1922 г. с изъятия в Красноярском Кафедральном БогородицеРождественском соборе. Некоторые исследователи полагают, что изъятие в Красноярске завершилось 8 мая [10, с. 116], хотя изъятия еще проводились вплоть до 21 мая [26, л. 82]. За время работы в Красноярске комиссия побывала в Кафедральном соборе пять раз (28 апреля, 2, 4, 6, 12 мая). За это время из собора было изъято более 1500 различных драгоценных предметов и церковной утвари, весом 16 п. серебра [27]. Всего же по г. Красноярску было изъято 79 п. церковного серебра, 1 ф. золота и более 500 шт. драгоценных камней [26, л. 63, 66].
Фактически в мае 1922 г. изъятие церковных ценностей проходило только в губернском центре, основная работа уездных комиссий пришлась на июнь. По городам Енисейской губернии ЕнгубКИЦЦ разрешила проводить изъятие только 7 мая, сельской округе рекомендовалось ждать [20, л. 59]. Исходя из этого положения следует, что хронологические рамки кампании несколько сдвинуты от периодизации И.В. Говоровой. В Енисейской губернии за май - середину июня была проведена основная масса изъятия церковных ценностей, лишь в отдаленных частях губернии кампания затянулась до конца сентября. Поэтому в регионе «основной этап» приходится на конец апреля - середину июня.

Основного сопротивления верующими не было оказано, за исключением пассивного сопротивления в виде отказов содействовать комиссии, прошений об оставлении богослужебных ценностей и др., что тормозило работу. В частности, при изъятии в Красноярском Кафедральном соборе 2 мая верующие вынесли протест против бывшего священника А. Муранова (в тот момент - члена комиссии по изъятию, эксперта по культам), присутствие которого они считали вне декрета. Ко всему прочему Муранов «сверстал папиросу» в храме около алтаря, чем еще больше вызвал недовольство верующих [26, л. 63]. Во многих церквях обнаруживалась утайка церковной утвари или отсутствие ее в храме при наличии в описи. Причины несоответствия по описи были разные. Так, в Красноярской Всехсвятской церкви одно отсутствующее Евангелие было «возложено на умершего священника» и «погребено вместе с ним» [26, л. 11], Красноярская Покровская церковь «в 1919 г. была ограблена» [26, л. 31] либо «прошло 50 лет, предметы состарились», как это было в Богоявленском соборе г. Енисейска [28, л. 45-46].

8 мая 1922 г. в Москве состоялось заседание КИЦЦ о «затяжке работ по РСФСР», связанных с изъятием церковных ценностей. Предлагалось принять меры к отстающим губкомам и задерживающим изъятие губерниям. «Недопустимо медлительная» работа по Сибири должна была завершиться к 1 июня 1922 г. [21, с. 191-192; 29, л. 79]. Енисейская губерния, не начавшая изъятие по уездам к этому времени, поняла невозможность завершения кампании к данному сроку, поэтому ЕнгубКИЦЦ согласовала с Сибирской комиссией по изъятию церковных ценностей завершение работ по губернии на 15 июня 1922 г. [30]. Однако уже 13 июня председатель ЕнгубКИЦЦ А.И. Кашников докладывал об итогах изъятия по уездам. К 13 июня работы были завершены в Канском, Ачинском уездах, в Красноярском уезде изъятие затянулось по ряду причин. Работа по Минусинскому уезду была только начата, а Туруханская комиссия к ней еще не приступила [20, л. 31]. К концу июня все же работа по уездам подходила к концу, исключением оставались наиболее отдаленные территории Енисейского уезда и Туруханский край. Последний на заседании ЕнгубКИЦЦ 13 июня обвинялся в том, что работа по-прежнему не начата. Ответ Туруханского исполкома последовал лишь 13 июля: туруханские власти признавали свою вину, но также указали, что получили почту только 11 июля [25, c. 116]. 
Изъятие церковных ценностей в Туруханском крае прошло в период 15 июля - 15 сентября 1922 г. Первое изъятие в Туруханском крае было совершено в Троицком монастыре, давшее 30 ф. 55 з. серебра и «целый ряд заявлений об оставлении предметов» [20, л. 177]. Последнее изъятие прошло 15 сентября вторым походом в Старотуруханский собор, которое дало лишь несколько фунтов серебра. 29 сентября 1922 г. ящик с церковными ценностями Туруханского края, весом 1 п. 1 ф. 76 з. серебра, отбыл на пароходе в г. Красноярск, где после пересчета реквизированное церковное серебро составило 8 ф. 19 з. [31, л. 2].

Завершение кампании в Енисейской губернии во многом приходится на третий, заключительный, этап изъятия церковных ценностей - прием ценностей в Енисейский губфинотдел и отправка в Центр (июнь 1922 г. - 21 марта 1923 г.). Еще в начале июня Енгубфинотдел докладывал в областную управу о том, что «кладовая переполнена», забитая ящиками с церковными ценностями, поэтому необходимо подготавливать высылку изъятого в Москву [32, л. 45]. 17 июня первая партия церковных ценностей, весом 152 п. серебра (54 ящика), была выслана в г. Екатеринбург на переплавку [32, л. 86-87].

В начале июля в финотдел поступило циркулярное письмо из валютного управления Наркомфина, за подписью Г.Я. Сокольникова, разъясняющее порядок пересылки серебряных церковных ценностей. Согласно указанию, серебро должно было отправляться на Монетный двор в Петроград, а золото предполагалось отправлять в Металлфонд [18, л. 4]. В течение июля Енгубфинотдел принял изъятые церковные ценности из церквей г. Красноярска, Красноярского, Енисейского, Канского, Ачинского, Минусинского уездов, но ценности все еще продолжали поступать, прием и высылка ценностей значительно затянулись. Это определило последующее несоответствие разных числовых данных, свидетельствующих об итогах кампании в губернии.

В конце сентября в губернский центр начали прибывать ценности, изъятые из церквей Туруханского уезда. К 11 ноября в кладовой губфинотдела оставалось еще 35 ящиков, которые «стесняли и без того тесную кладовую», поэтому местные финансовые органы просили отправить эти ценности следующей командировкой товарным вагоном [33, л. 3]. 10 декабря из г. Новониколаевска в Енгубфинотдел поступило письмо, в котором говорилось, что он «слишком запоздал сравнительно с другими финотделами в деле изъятия ценностей» [33, л. 9]. Кроме того, центральные сибирские органы смутило, что финотдел Енисейской губернии требует кредиты на перевозку ценностей, «в то время как другие губернии ограничились скромными ресурсами» [34, л. 9]. Тем не менее 18 декабря Енгубфинотдел получил 30 тыс. руб. на переупаковку ценностей, которые были распределены между десятью сотрудниками финотдела по 3 тыс. руб. на каждого [18, л. 5-6].

В декабре 1922 г. - январе 1923 г. церковные ценности все еще поступали из уездов. Так, в декабре из Енисейского уезда прибыло несколько ящиков с ценностями, два ящика весом более 3 пудов были доставлены из Канского уезда, затем в январе в Красноярск была доставлена последняя партия цер- ковных ценностей из Енисейского уезда $[18$, л. 15 , 36-37]. 29 января 1923 г., проводя проверку хода приемки и высылки ценностей, Енисейская РабочеКрестьянская инспекция (ЕнгубРКИ) заключила, что финансовыми органами не соблюдаются «самые элементарные требования», а именно отсутствует общая опись изъятого, нет единых общих сведений о весе ценностей, а также упаковка была «настолько небрежной, что из ящиков «сыпались» церковные ценности, серебряные монеты и пр. [33, л. 15]. К 6 марта 1923 г. в Енгубфинотделе оставалось еще 16 ящиков церковных ценностей, которые 21 марта 1923 г. были отосланы в Екатеринбургский губфинотдел $[18$, л. 17, 54]. Таким образом, последние 32 п. церковного серебра были отправлены из Енисейской губернии. Завершающим «штрихом» стала передача предметов музейного значения из губфинотдела в Музей Приенисейского края, произошедшая в конце апреля 1923 г. [34, л. 100].

Иными словами, несмотря на подсчет изъятых церковных ценностей и их отправку еще с середины июня 1922 г., завершение этого процесса пришлось лишь на конец марта 1923 г. Непосредственно «изъятия» завершились в Енисейской губернии 15 сентября 1922 г., поэтому в начале декабря Агитационный отдел с радостью сообщал о том, что кампания проведена успешно, так как в регионе произошел обновленческий раскол [35, л. 9 об].

Количество изъятых ценностей по Енисейской губернии (табл. 1) - вопрос дискуссионного характера. Так, в одной из записок из губфинотдела количество изъятого составляет 307 п. церковного серебра [33, л. 17], по справке председателя губернской комиссии по последствиям голода от 15 июня 1923 г. 257 п. серебра [31, л. 2], по телеграмме председателя ЕнгубКИЦЦ в Сибкомпомгол 1 августа 1922 г. - 240 п. [36, л. 85]. Количество ценностей в 307 п. серебра в других источниках не встречается, за исключением данной записки, обстоятельства составления которой на сегодняшний день неизвестны, на самой записке какие-либо подписи и печати отсутствуют. Вероятнее всего, наиболее точное количество серебра указано в справке по данным председателя губернской комиссии по последствиям голода - 257 п. Количество изъятого золота составляет 3 ф. 84 зол. (по некоторым данным 1 ф. 33 з. [30]), из которых 16 з. 54 д. - монеты, более 7 п. серебра оставлено для музея [31, л. 2; 33, л. 17].

таблица 1 - Количество изъятых церковных ценностей в Енисейской губернии

\begin{tabular}{|l|c|c|c|}
\hline \multicolumn{1}{|c|}{ Уезд } & $\begin{array}{c}\text { Церковно- } \\
\text { го серебра }\end{array}$ & Золота & $\begin{array}{c}\text { Драгоценных } \\
\text { камней }\end{array}$ \\
\hline $\begin{array}{l}\text { Краснояр- } \\
\text { ский }\end{array}$ & 116 п. 37 ф. & 2 ф. 7 з. 51 д. & $\approx 660$ \\
\hline Канский & 33 п. 3 ф. & 2 з. & сведений нет \\
\hline Ачинский & 26 п. 38 ф. & - & $\approx 329$ \\
\hline $\begin{array}{l}\text { Минусин- } \\
\text { ский }\end{array}$ & 26 п. 6 ф. & 55 з. 55 д. & сведений нет \\
\hline $\begin{array}{l}\text { Енисей- } \\
\text { ский }\end{array}$ & 53 п. 27 ф. & 31 з. 74 д. & $\approx 534$ \\
\hline $\begin{array}{l}\text { Турухан- } \\
\text { ский }\end{array}$ & 8 ф. & - & - \\
\hline Итого: & 257 п. 1 ф. & 3 ф. 84 д. & 2136 шт. \\
\hline
\end{tabular}

Самарский научный вестник. 2017. Т. 6, № 2 (19) 
Таким образом, изъятие церковных ценностей в Енисейской губернии продлилось чуть больше года «в полном цикле», с начала марта 1922 г. по конец марта 1923 г., по причине затяжной отправки ценностей в Москву. Предписание закончить работы по Сибири к 1 июня или к 15 июня по Енисейской губернии было нарушено с опозданием в несколько месяцев, однако основная часть изъятого к концу 1922 г. все же была доставлена по назначению. Из особенностей проведения кампании в регионе можно выделить две: затяжной характер и мирное проведение. Несмотря на «несочувственное» отношение населения к изъятию, крупных эксцессов не было, а количество человек, привлеченных к судебным разбирательствам, если верить данным Енисейского губтрибунала, составляло всего 10 человек [37, л. 10]. Как и во многих губерниях России, в деле изъятия ценностей православное духовенство Енисейской губернии раскололось на «обновленцев» и «тихоновцев», что нарушило каноническое управление епархией. Изъятие более 200 п. церковного серебра лишило религиозные организации большей части своего имущества, существенно подорвав их экономическое благосостояние. Кроме того, основная масса изъятых ценностей являлась богослужебными предметами, что не могло не отразиться на духовной жизни региона.

\section{СПИСОК ЛИТЕРАТУРЫ:}

1. Одинцов М.И. Русская православная церковь накануне и в эпоху сталинского социализма, 19171953 гг. М.: РОССПЭН, 2014. 421 с.

2. Васильева О.Ю. Русская православная церковь и Советская власть в 1917-1927 годах // Вопросы истории. 1993. № 8. С. 40-54.

3. Кривова Н.А. Власть и церковь в 1922-1925 гг. Политбюро и ГПУ в борьбе за церковные ценности и политическое подчинение духовенства. М.: АИРОХХ, 1997. 247 с.

4. Говорова И.В. Изъятие церковных ценностей в 1922 г. в контексте государственно-церковных отношений: автореф. дис. ... канд. ист. наук. М., 2006. $27 \mathrm{c}$.

5. Каиндина Т.В. О работе омской губернской комиссии по изъятию церковных ценностей [Электронный ресурс] // http://iaoo.ru/note157.html.

6. Шкуратова Д.И. Изъятие церковных ценностей на Алтае и «следственное дело группы Долинина» // Мир Евразии. 2013. № 4 (23). С. 63-66.

7. Мавлютова 3.Ш. К вопросу об изъятии церковных ценностей в Тюменской губернии в 1922 г. // Вестник археологии, антропологии и этнографии. 2007. № 7. С. 172-176.

8. Смолина И. К вопросу об изъятии церковных ценностей в Иркутской губернии [Электронный реcypc] // http://old.pravostok.ru/ru/journal/jhistory/?id=697.

9. Цыремпилова И.С. Экономическая политика государства по отношению к религиозным организациям в 1920-1930-е гг. (На примере Иркутской и Забайкальской епархий) // Иркутский историкоэкономический ежегодник. 2013. С. 285-293.

10. Доброновская А.П. Отделение церкви от государства в Енисейской губернии (1920-1922 гг.) // Сибирь в XVII-XX веках: Проблемы политической и социальной истории: Бахрушинские чтения 1999-
2000 гг.; Межвуз. сб. науч. тр. / под ред. В.И. Шишкина. Новосибирск: НГУ, 2002. С. 110-119.

11. Доброновская А.П. Религиозная жизнь населения Приенисейского региона на переломе эпох (1905-1929 гг.): дис. ... канд. ист. наук. Красноярск, 2007. 237 c.

12. Выдрин Е.В., Бобрик И.Е. К вопросу об изучении кампании по изъятию церковных ценностей в Енисейской губернии // Молодежь и XXI век - 2016: мат-лы VI междунар. молодежной науч. конф. В 4 т. Курск, 2016. С. 30-33.

13. Холина М.В. Ломка большевиками РПЦ и православных традиций в Красноярском крае (19201930-е гг.) // Новый исторический вестник. 2009. № 21. C. $31-41$.

14. Малашин Г.В. Красноярская (Енисейская) епархия РПЦ: 1861-2011 гг. Красноярск: ИД «Восточная Сибирь», 2011. 480 с.

15. Шекшеев А.П. Енисейское крестьянство в эпоху социальных потрясений: между верой и безверием // XI Красноярские краевые образовательные Рождественские чтения (Красноярск, 12-14 января 2011 г.). Красноярск, 2011. С. 98-118.

16. Покровский Н.Н. Предисловие // Архивы Кремля. В 2 кн. / Кн. 1. Политбюро и церковь. 19221925 гг. М.-Новосибирск: РОССПЭН, «Сибирский хронограф», 1997. С. 7-109.

17. Русские патриархи XX века. Судьбы Отечества и Церкви на страницах архивных документов. М.: РАГС, 1999. 334 с.

18. Государственный архив Красноярского края (далее - ГАКК). Ф. Р-1134. Оп. 1. Д. 196.

19. ГАКК. Ф. П-1. Оп. 1. Д. 141.

20. ГАКК. Ф. Р-1303. ОП. 1. Д. 83.

21. Петров С.Г. Документы делопроизводства Политбюро ЦК РКП(б) как источник по истории Русской церкви (1921-1925 гг.). М.: РОССПЭН, 2004. $408 \mathrm{c}$.

22. Свердлов А. Митинг об изъятии из храмов золота и серебра 26 марта 1922 года // Красноярский рабочий. 1922. № 71 .

23. Грозное напоминание // Красноярский рабочий. 1922. № 90.

24. Церковь и голод // Канский крестьянин. 1922. 1 июня.

25. Бобрик И.Е. Отделение церкви от государства в Туруханском крае: национализация, вскрытие мощей, изъятие церковных ценностей (1920-1922) // Енисейский Север: история и современность: сб. науч. тр. Красноярск, 2016. С. 109-123.

26. ГАКК. Ф. Р-1134. Оп. 1. Д. 127.

27. ГАКК. Ф. Р-1134. ОП. 1. Д. 148.

28. ГАКК. Ф. Р-1134. ОП. 1. Д. 128.

29. Государственный архив Новосибирской области (далее - ГАНО). Ф. Р-1. Оп. 2. Д. 98.

30. Религия и общество в Приенисейской Сибири. 1920-1930-е годы. Красноярск: Поликор, 2011. 400 с.

31. Государственный архив Российской Федерации (далее - ГАРФ). Ф. 1065. Оп. 4. Д. 61.

32. ГАКК. Ф. Р-1134. ОП. 1. Д. 184.

33. ГАКК. Ф. Р-1134. Оп. 1. Д. 197.

34. ГАРФ. Ф. А2307. Оп. 3. Д. 348.

35. ГАКК. Ф. П-1. ОП. 4. Д. 1.

36. ГАНО. Ф. Р-656. Оп. 1. Д. 79.

37. ГАНО. Ф. Р-656. Оп. 1. Д. 74. 


\section{CONFISCATION OF CHURCH PROPERTY IN THE YENISEI PROVINCE (PERIODIZATION AND OUTCOME)}

(C) 2017

Vdovin Alexander Sergeevich, candidate of historical sciences, professor of Museology and Cultural Heritage Department

Bobrik Iliya Eugenievich, student of History Faculty

Krasnoyarsk State Pedagogical University named after V.P. Astafiev (Krasnoyarsk, Russian Federation)

Abstract. The following paper focuses on the confiscation of church property in the Yenisei province, which was held from March 1922 to March 1923. Hunger in Volga Region was the reason for the campaign. The authors on the basis of central and regional archives review the results of the campaign, which was described earlier in the regional historiography. They also give periodization of the process in the province. The authors believe that the confiscation of church property in the Yenisei province took place in three uneven stages. The last phase was delayed for more than six months. The periodization is based on Krasnoyarsk and Moscow correspondence about the campaign. Yenisei province as most lagging in the campaign finished confiscation by the end of 1922 . The authors have traced the path of church property of the local financial departments to the provincial finance department and then from Krasnoyarsk to Yekaterinburg and Moscow.

Keywords: church and Soviet State; church property; confiscation; Russian Orthodox Church; Yenisei province; Pomgol; Yenisei Siberia; religious organizations; hunger in Volga Region; Yenisei diocese; church silver; antireligious policy; economic policy.

УДК 94 (73)

\section{ЗАПАСНАЯ СТОЛИЦА СССР: ОЦЕНКИ АМЕРИКАНСКОЙ ПРЕССЫ И СПЕЦСЛУЖБ}

(C) 2017

Буранок Сергей Олегович, доктор исторических наук, доцент кафедры всеобщей истории, права и методики обучения Левин Ярослав Александрович, кандидат исторических наук, младший научный сотрудник кафедры всеобщей истории, права и методики обучения

Соколова Анна Вячеславовна, студент исторического факультета

Самарский государственный социально-педагогический университет (2. Самара, Российская Федераџия)

Аннотаиия. В данной статье впервые в самарском краеведении предпринято исследование того, какое место и значение г. Куйбышев занимал в общественном мнении союзников СССР. Став запасной столицей, Куйбышев перестал быть только одним из региональных центров Советского Союза, превратившись в город, известный и значимый во всем мире. В данной статье использованы многие уникальные документы США о Куйбышеве времен войны. Кроме того, на их основе проанализированы становление и восприятие образа запасной столицы в американском обществе. Изучение истории Куйбышева как второй столицы под таким углом является важным для имагологии, краеведения, компаративистики. Проведенное исследование показало, как конструировался образ города Куйбышева в условиях Второй мировой войны, как менялось его восприятие. Также важно отметить, что в статье используются и данные спецслужб США, что позволяет понять, какое место Куйбышеву на тот момент отводили представители разведывательного сообщества Америки. Изучение образа Куйбышева в оценках американских спецслужб открывает исследователям возможность познакомиться с их работой с нового ракурса. Помимо этого в статье проанализировано влияние тех или иных журналистов на формирование образа Куйбышева. Сделанные в данной статье выводы, а также введение в оборот новых документов позволит в будущем углубить и расширить данную тему.

Ключевые слова: Вторая мировая война; Великая Отечественная война; Куйбышев; Самара; Самарская область; имагология; запасная столица; Федеральное бюро расследований; Ассошиэйтед Пресс; Соединенные Штаты Америки; Генри Кэссиди; Эдди Гилмор; Генри Шапиро; Уолтер Керр; Арчибальд Стил; спецслужбы; Пёрл-Харбор; Тихоокеанская война.

«Куйбышев военных лет» - различным аспектам этой многогранной темы посвящено множество публикаций. В них досконально исследована экономика Куйбышевской области, деятельность партийных, государственных и общественных структур, культурная жизнь запасной столицы, вклад работников науки и образования в победу, демографическая ситуация и т.д. Но все еще остаются малоизученные проблемы истории Куйбышева военного периода, одной из которых является восприятие «военной столицы» общественностью союзников. Важность изучения подобной проблемы заключается не только в расширении научных знаний по истории Самары, но и в конкретизации образа «советского союзника», сформировавшегося у американцев и англичан в 1941-1945 гг. Первые сообщения о Куйбышеве в США появляются 18-20 октября 1941 г., а уже 2224 октября 1941 г. почти каждая газета США написала про Куйбышев.

Вынужденный переезд дипломатов и журналистов в Куйбышев сыграл большую роль в формировании общего позитивного настроя общественности США и Великобритании: 22 октября многие корреспонденты написали в свои редакции, что через Куй- 